\title{
Spatial heterogeneity of benthic copepods: a comparative aspect on composition, abundance, and correlation
}

\author{
R Jayabarathi, , G Padmavati and I Anandavelu
}

\begin{abstract}
Background: Comparing meiofaunal assemblages in the seagrass zone with bare sediment will provide information on the structuring factors and phytal preferences of meiobenthic invertebrates since differences in density and diversity of meiofauna are to be expected between vegetated and bare zones.

Results: A total of 11 groups of meiofauna, with harpacticoids dominating (51\%) and comprising 48 species within 14 families, have been identified. At all localities, the following harpacticoids were found to be relatively abundant, contributing $30.9 \%$ of all harpacticoids: Longipedia weberi, Canuellina nicobaris, Scottolana longipes, and Parastenhelia hornelli. A highly significant correlation $\left(r=0.987, r^{2}=0.974, F_{(1,9)}=337.3, P<0.001\right)$ of meiofaunal assemblage was found between seagrass leaf blades and the canopy sediment compared to bare sediment which was found to have a moderate correlation $\left(r=0.543, r^{2}=0.294, F_{(1,9)}=3.756, P=0.085\right)$. In addition, the abundance of harpacticoids was significantly higher (ANOVA, $F_{(2,144)}=19.53, P<0.001$ ) in seagrass sediments and differed markedly from blades and bare sediments, and the composition was unique in the different zones of the present study.
\end{abstract}

Conclusions: Productive seagrass ecosystems are as yet inadequately studied in the Andaman Islands. This study provides a first step to characterize a faunal group from the seagrass community.

Keywords: Andaman; Harpacticoids; Meiofauna; Seagrass; Sediment

\section{Background}

Meiofauna has been considered as a dynamic element of the marine environment and an integral part of the benthic trophic food chain (Watzin 1983; Higgins and Thiel 1988; Mascart 2010). They inhabit a wide diversity of habitats from the littoral zone to great depths, as associates or parasites of several multicellular animals and plants, and also in sea ice (Coull et al. 1982; Grainger 1991). The patchiness of meiobenthos has been influenced by availability of food and oxygen and other environmental factors (Hicks and Coull 1983; Mantha et al. 2012a) and even by macrofaunal bioturbation (Ólafsson and Moore 1992; Ólafsson 2003). Although sediment granulometry is a major structuring factor of meiofaunal population (Ólafsson 1995; Boucher 1997; Ndaro and Ólafsson 1999; Semprucci et al. 2010), benthic

\footnotetext{
* Correspondence: arjayabarathi@gmail.com

Department of Ocean Studies and Marine Biology, Pondicherry University, Brookshabad Campus, P. Bag. No. 01, Chakkargoan, Port Blair 744112, Andaman and Nicobar Islands, India
}

primary producers such as micro- and macroalgae and higher plants have great influence on the assemblages of benthic fauna which continue to live an epifaunal transition mode of life (Jayabarathi et al. 2012; Anandavelu et al. 2013). The physical and biological characteristics of macrophytes form a dynamic community of animals which subsist as epifauna on them. Seagrass beds are some of the most productive parts of coastal ecosystems with estimated annual primary production comparable to that of tropical rain forests (Duarte and Chiscano 1999; Hemminga and Duarte 2000). They provide energy through detritus decomposition and direct herbivory pathways. The rhizomal root system stabilizes the sediment, while densely growing leaves reduce current velocity and encourage the settling of further particles from suspension.

Shallow water vegetation of seagrass patches is also widespread and has an important role in the coastal ecosystem of the Andaman archipelago (Jagtap 1991; Thangaradjou et al. 2010). The coastal waters of 
Andaman Islands are recognized as an important stronghold for marine biodiversity and contain some of the least impact marine habitats such as seagrass. They are among the world's most productive marine environments, hosting a wide variety of associated macro- and meiofauna (Stoner et al. 1995; Nakaoka 2005). The reviews of seagrass associates reveal that harpacticoid copepods were the key taxon among the macrophytal communities (Arunachalam and Nair 1988; De Troch et al. 2001; 2003). In addition to that, copepods are often considered as the most important taxon as they contribute to the total biomass in terms of faunal abundance, both in pelagic (Padmavati et al. 1998) and benthic environs (Wells 1976; Wells and Rao 1987; Mantha et al. 2012a, b). Harpacticoida are primarily benthic and a key component of the coastal benthos which contributes significantly to the transfer of energy to higher trophic levels (Coull 1990; De Troch et al. 1998; Turner 2004; Danovaro et al. 2007).

The archipelago system has been playing an important role for the protection of marine biodiversity and comprised of nine species of seagrass (Jagtap 1991). Earlier studies have dealt mainly with the taxonomic and distributional aspects and environmental assessment of Indian seagrass (Jagtap and Inamdar 1991; Thangaradjou et al. 2007, 2010; Umamaheswari et al. 2009; Nobi et al. 2011; Sulochanan et al. 2011). However, with a sole reference work of Das (1996), the structure and function of the seagrass of Andaman and Nicobar Islands remain poorly understood. The importance of such fragile communities as a major ecosystem that improves the fishery productivity of the marine systems (De Troch et al. 1998; Unsworth et al. 2014) remains largely unevaluated. The studies relating meiofaunal assemblage with the seagrass ecosystem around the Indian waters are meager (Arunachalam and Nair 1988; Jayabarathi et al. 2012). Further, the knowledge of abundance and composition of faunal assemblages in seagrass beds compared to unvegetated sediment will provide information on the structuring factors and the phytal preferences of meiobenthic invertebrates. The epiphytic load and organic nutrients are often associated with macrophyte production in the benthic region, and thus, differences in density and diversity of meiobenthos may be expected between vegetative and un-vegetative areas. In the present study, the meiofaunal assemblage was investigated by comparing sediments of seagrass vegetation and the adjacent bare region.

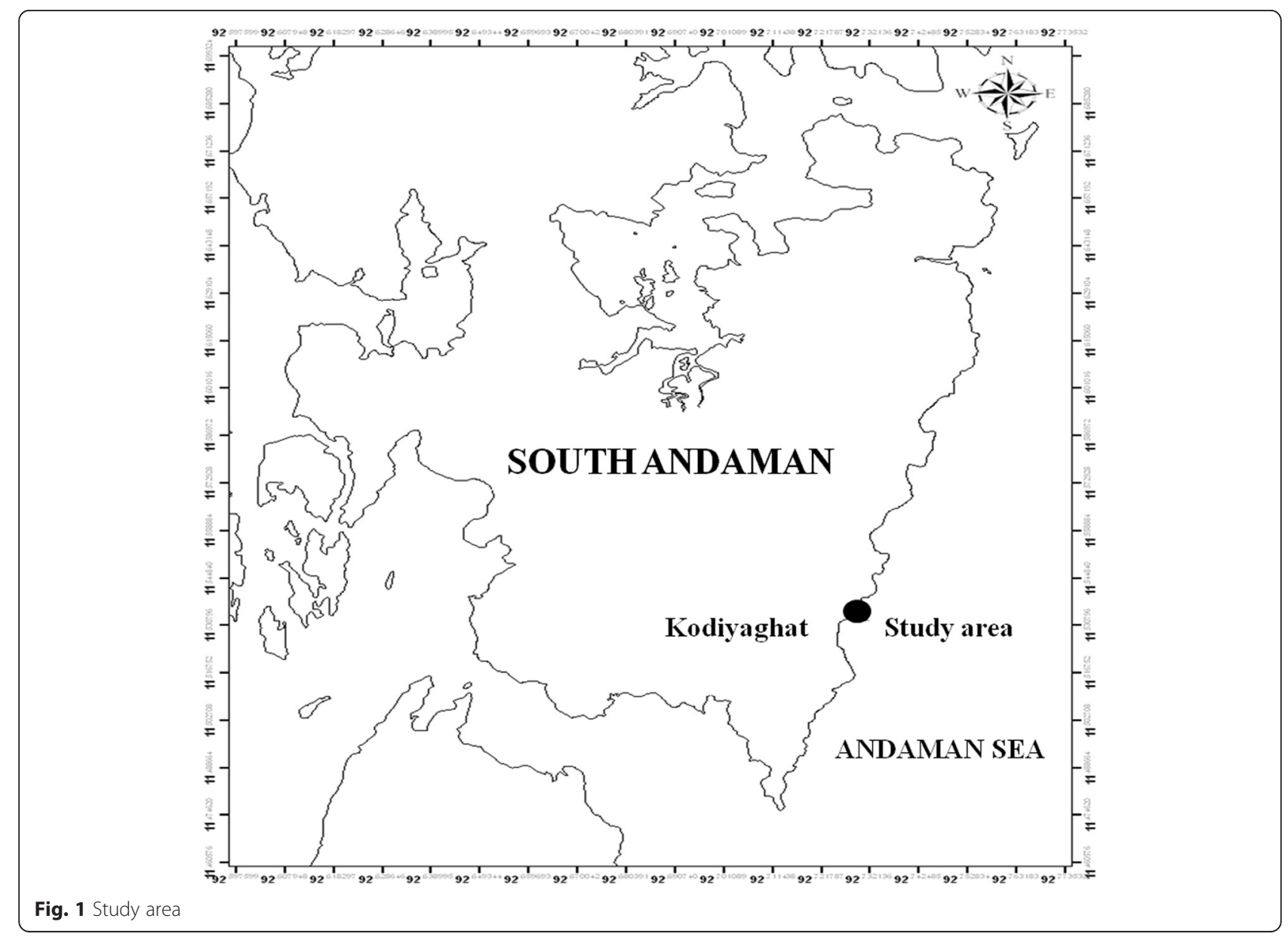




\section{Methods}

\section{Study area}

The unique and protected areas of Andaman and Nicobar Islands are prominent biodiversity hotspots. This Archipelago system partitions the Andaman Sea from the Bay of Bengal (Varkey et al. 1996). All samples examined in this study were collected from Kodiyaghat $\left(11^{\circ} 31^{\prime} \mathrm{N}, 092^{\circ} 43^{\prime}\right.$ E), South Andaman (Fig. 1). The locality is a rocky shore with intermittent sediment supporting macrovegetation of seagrass Thalassia hemprichii patches throughout the area. The prevailing sediment types in the area are sandy sediment mixed with gravel or boulder.

\section{Sampling}

A small patch of seagrass was selected for our study near Rajiv Gandhi Centre for Aquaculture (RGCA, MPEDA) aquaculture station. Samples were collected for a 3month period from December 2010 to February 2011 at low tide. We used a $32 \mathrm{~cm} \times 32 \mathrm{~cm}$ quadrat for collection of seagrass blades. Grass blades inside the quadrat were gently clipped at the base without uprooting the plant and transferred immediately into a plastic bag. Care was taken to avoid the contamination of blades by sediment-dwelling species. Subsequently, collection of vegetated sediment and bare sediment was carried out with the help of PVC cores of 3-cm internal diameter (surface area $7.065 \mathrm{~cm}^{2}$ ) inserted into the sediment down to a depth of $7 \mathrm{~cm}$. The core was removed and the content was placed into a plastic bag. The collection of bare sediment did not exceed about $5 \mathrm{~m}$ from the seagrass patch. Three replicates were collected from vegetated and bare sediment zones, whereas in the case of seagrass blades, only two replicates were collected because of the intention to condense overexploitation of sparsely distributed seagrass patches in the sampling site. In parallel to all sampling events, environmental parameters such as temperature, salinity, and $\mathrm{pH}$ (7.4 to 8.7) were measured in the adjacent regions from the study area. Temperature in the study area was decreased from December 2010 to February 2011 such as 31, 28, and 26 ${ }^{\circ} \mathrm{C}$, whereas the salinity was increased by 21,29 , and 34 PSU, respectively. Variations in salinity and temperature generally resulted from local precipitation and the time of sampling (low tide) during December to February in the study area. In the laboratory, all samples were stained with Rose Bengal solution $\left(0.5 \mathrm{~g} \mathrm{~L}^{-1}\right)$. The content of core samples was sieved through $500-$ and $63-\mu \mathrm{m}$ standard test sieves and placed into plastic vials. The same strategy was followed for extruding the phytal fauna after rinsing the leaf blades with filtered seawater. All samples were preserved with $4 \%$ buffered formaldehyde. In the present study, meiobenthos other than harpacticoids was identified up to a possible level. Harpacticoid copepods were sorted, enumerated, and identified to species level (Lang
1948; Lang 1965; Wells 1976; Wells and Rao 1987; Giere 1993; Higgins and Thiel 1988) by using a stereoscope and inverted microscope. Animal abundance was expressed as the number of individuals per $10 \mathrm{~cm}^{2}$ of the bottom surface.

\section{Statistical analysis}

The variation in the abundance of Harpacticoida between the sampled zones was accessed by one-way ANOVA. The statistical analysis of correlation and regression was carried out using Microsoft Excel (ver. MS Office 2007) to access the relationship between the meiofaunal abundance in seagrass compared to bare sediment. Diversity indices such as the Shannon-Wiener diversity $\left(H^{\prime}\right)$ based on $\log _{\mathrm{e}}$ and Pielou's evenness $\left(J^{\prime}\right)$ of Harpacticoida between the seagrass leaf blade (SLB), seagrass canopy sediment (SSD), and unvegetated bare sediment (BSD) were conducted. The Bray-Curtis similarity index was applied on square-root transformed abundance data to access the relationship between the sampling zones and between the harpacticoid species of various zones of collection. Plymouth Routines in Multivariate Ecological Research (PRIMER, Clarke and Gorley 2006) computer package was used for diversity indices and cluster analysis.

\section{Results}

Totally, 11 major groups of meiofaunal size organisms were identified by this study. The dominant groups were Harpacticoida (51 \%) followed by Nematoda (12.6\%) and Foraminifera (12\%). Other groups consist of Ostracoda and Polychaeta which are 7 and $6.3 \%$, respectively. The remaining groups such as Nemertea, Decapoda, Mollusca, Amphipoda, Isopoda, and Calanoida were less than $2 \%$. Harpacticoid copepods (SSD: $X \pm \mathrm{SD}=21.38 \pm 5.34, n=$ 3; SLB: $X \pm \mathrm{SD}=5.76 \pm 4.34, n=3$ ) were the most dominating meiofaunal component in the seagrass zone (Fig. 2a, b). In addition to harpacticoids $(X \pm \mathrm{SD}=4.31 \pm 5.08, n=$ $3)$, other groups such as foraminiferans $(X \pm \mathrm{SD}=4.26 \pm$ 4.31, $n=3)$ and nematodes $(X \pm \mathrm{SD}=4.05 \pm 4.54, n=3)$ were also dominant in the unvegetated region (Fig. 2c). A significantly very high correlation $\left(r=0.987, r^{2}=0.974, F_{(1,9)}=\right.$ 337.3, $P<0.001$ ) of meiofaunal assemblage was found between SLB and SSD compared to the bare sediment which was found to have only a moderate correlation $\left(r=0.543, r^{2}=\right.$ $\left.0.294, F_{(1,9)}=3.756, P=0.085\right)$.

A total of 14 families comprising 48 species of harpacticoids have been recorded. All families were found in the seagrass canopy sediment and leaf blades except Paramesochridae in the latter zone. Eight of the families were common in all zones (Canuellidae, Cylindropsyllidae, Diosaccidae, Ectinosomatidae, Laophontidae, Longipediidae, Parastenheliidae, and Tetragonicipitidae). Families such as Porcellidiidae, Peltidiidae, Thalestridae, Ameiridae, and Cletodidae were not found in the bare sediment (Table 1). 


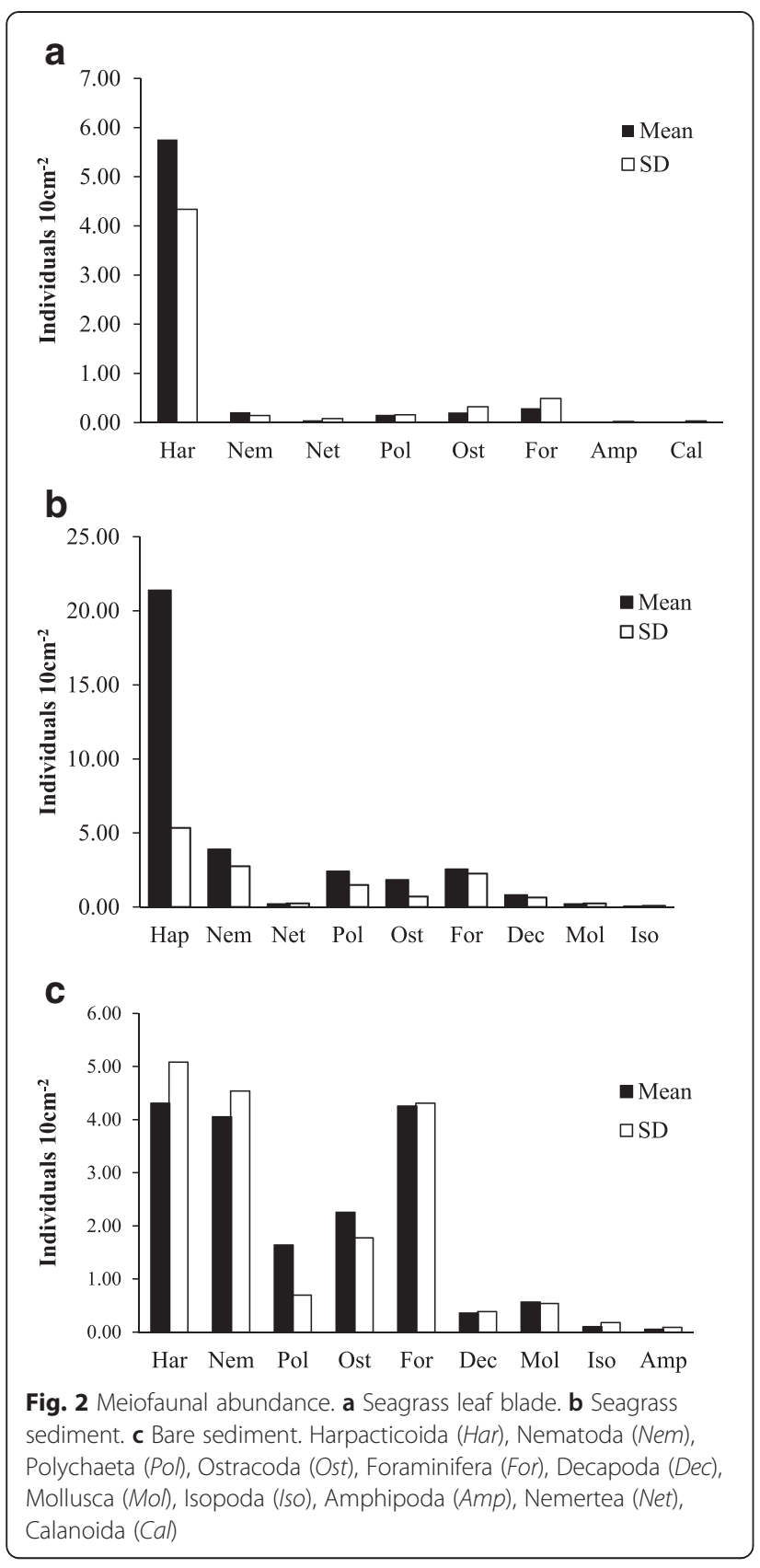

Diosaccidae was the most highly represented family with 12 species in the SLB. Canuellidae with six species was found to be common in both zones of seagrass. Other families such as Thalestridae and Ectinosomatidae were represented by five and four species, respectively, in the blades. The dominant species of each family in the zones were marked with an asterisk (Additional file 1: Table S1). The dendrogram resulting from the cluster analysis of the average abundance shows the similarity of the families of harpacticoid copepods (Fig. 3). The presence of two major clusters of families became apparent with one of the clusters comprising families such as Porcellidiidae, Ameiridae, and
Peltidiidae which were found to be the numerically dominant harpacticoid copepods of the seagrass leaf blade and sediment zones. The second major cluster was further classified with two families Paramesochridae and Cylindropsyllidae forming one cluster, with rare individuals found in the bare sediments. Cluster analysis for the harpacticoid species showed three distinct assemblages of species based on the zone of sample collection. Species harbored on SLB appeared as a separate group, while the species found in SSD and BSD were clustered, respectively, in discrete groups (Fig. 4 and Additional file 1: Table S1).

The Harpacticoida were numerically dominant in the canopy sediment, whereas assemblage in the leaf blade and canopy sediment showed high species richness (Fig. 5a, b) and was numerically dominated by Canuellina nicobaris and Scottolana longipes. Overall, 17 species were found to be regular in all regions. Species, namely, Laophonte spinicauda, Helmutkunzia variabilis, Metamphiascopsis nicobaricus, Diosaccus monardi, Metamphiascopsis hirsutus, Neodatylopus trichodes, and Eupelte aurulenta, were found only on the blades, whereas Longipedia andamanica, Peltidium ovale, Apolaophonte hispida, and Echinolaophonte mirabilis were observed in the sediment zones.

In all three zones, Longipedia weberi, Canuellina nicobaris, Scottolana longipes, and Parastenhelia hornelli were found to be relatively abundant, contributing 30.9 $\%$ of all harpacticoids. Other species such as Noodtiella ornamentalis $(6.4 \%)$ were the next dominant in blades. Ectinosoma reductum and Halectinosoma tenuireme were common in relative abundances of 5.4 and $4.3 \%$, respectively, in the seagrass zone. In addition, Halophytophilus simplex (3.0 \%), Diathrodes cystoecus (4.1\%), Idomene maldivae (3.0\%), Cletodes dentatus (3.2\%), and Euterpina acutifrons (3.2 \%) were found on seagrass leaf blades. In seagrass sediment, Typhlamphiascus ovale, Phyllopodopsyllus crenulatus, Scottolana rostrata, Apolaophonte hispida, and Macrosetella gracilis occurred with a relative abundance between 3.6 and $4.6 \%$.

The abundance of harpacticoids was significantly higher (ANOVA, $\left.F_{(2,144)}=19.53, P<0.001\right)$ in vegetated sediments and differs markedly from seagrass blades and bare sediments. Among the three zones, higher congregation of copepods was found to be in the seagrass canopy sediment. Regarding the species richness, leaf blades were higher than in the remaining regions (Fig. 5). The Shannon index shows higher diversity of copepods in the vegetated region than in the bare sediment where as the equitability of species was more or less equal in all zones during the period of collection (Fig. 5c, d).

\section{Discussion and conclusions}

Associated meiofauna of major ecosystems like coral reef and seagrass habitats have been investigated from Indian 
Table 1 Density (mean \pm SE) and number of species of harpacticoid families

\begin{tabular}{|c|c|c|c|c|c|c|}
\hline \multirow[t]{2}{*}{ Families } & \multicolumn{3}{|c|}{ Density (individuals $10 \mathrm{~cm}^{-2}$ ) } & \multicolumn{3}{|c|}{ Number of species } \\
\hline & SLB & SSD & BSD & SLB & SSD & BSD \\
\hline Ameiridae & $0.22 \pm 0.06$ & $0.92 \pm 0.18$ & - & 1 & 1 & - \\
\hline Canuellidae & $3.98 \pm 0.78$ & $19.85 \pm 0.65$ & $0.77 \pm 0.12$ & 6 & 6 & 2 \\
\hline Cletodidae & $0.68 \pm 0.23$ & $2.92 \pm 0.24$ & - & 2 & 2 & - \\
\hline Cylindropsyllidae & $0.66 \pm 0.14$ & $0.62 \pm 0.05$ & $0.36 \pm 0.10$ & 2 & 3 & 1 \\
\hline Diosaccidae & $1.96 \pm 0.25$ & $5.54 \pm 0.19$ & $4.06 \pm 0.20$ & 12 & 7 & 7 \\
\hline Ectinosomatidae & $2.98 \pm 0.6$ & $11.54 \pm 0.45$ & $0.69 \pm 0.07$ & 4 & 4 & 2 \\
\hline Laophontidae & $0.28 \pm 0.02$ & $3.69 \pm 0.55$ & $0.71 \pm 0.06$ & 2 & 3 & 3 \\
\hline Longipediidae & $1.38 \pm 0.16$ & $3.23 \pm 0.37$ & $3.37 \pm 0.91$ & 1 & 2 & 1 \\
\hline Paramesochridae & - & $0.92 \pm 0.09$ & $1.42 \pm 0.38$ & 0 & 1 & 1 \\
\hline Parastenheliidae & $0.94 \pm 0.11$ & $3.23 \pm 0.18$ & $0.49 \pm 0.08$ & 1 & 1 & 1 \\
\hline Peltidiidae & $0.04 \pm 0.01$ & $0.31 \pm 0.1$ & - & 1 & 1 & - \\
\hline Porcellidiidae & $0.28 \pm 0.09$ & $0.15 \pm 0.05$ & - & 1 & 1 & - \\
\hline Tetragonicipitidae & $0.8 \pm 0.12$ & $4.00 \pm 0.35$ & $0.84 \pm 0.08$ & 3 & 3 & 3 \\
\hline Thalestridae & $2.08 \pm 0.2$ & $2.62 \pm 0.18$ & - & 5 & 4 & - \\
\hline
\end{tabular}

SLB seagrass leaf blade, SSD seagrass sediment, $B S D$ bare sediment

waters (Arunachalam and Nair 1988; Ansari and Parulekar 1994) and elsewhere worldwide (Mascart et al. 2013, 2015; De Troch et al. 2008; Gheerardyn et al. 2008, 2009, 2010; Callens et al. 2011). As for the meiofauna, nematodes generally dominate benthic sediments followed by harpacticoid copepods (Ólafsson 1995), whereas occasionally other taxa may also dominate marine sediment because of the patchiness of meiofauna in distribution (Thistle 1978; McLachlan 1978; Findlay 1981; Mantha et al. 2012a, b). Reviews of the meiobenthos of marine sediments have showed that lower copepod abundances are encountered in all depth zones (Ólafsson 1995). In the present report, out of the 11 recorded meiofaunal taxa, harpacticoid copepods were the dominant component of sediments in the seagrass zone $(64 \%)$ which differed markedly from bare sediment and leaf blades (ANOVA, $\left.F_{(2,144)}=19.53, P<0.001\right)$ (Fig. 2). A similar pattern of harpacticoid dominance was reported in the Bay of Bengal; however, the samples were collected from the intertidal region of the Chennai coast in comparison with the present analysis of the bare sediment zone (Mantha et al. 2012a, b). It may be convenient to consider seagrass and canopy sediment as separate environments, while the correlation between meiofaunal taxa of SLB and SSD was significantly very high $(r=$ $\left.0.987, r^{2}=0.974, F_{(1,9)}=337.3, P<0.001\right)$ which provided a conclusive evidence of interaction within the vegetative environment. The results of the present study are comparable

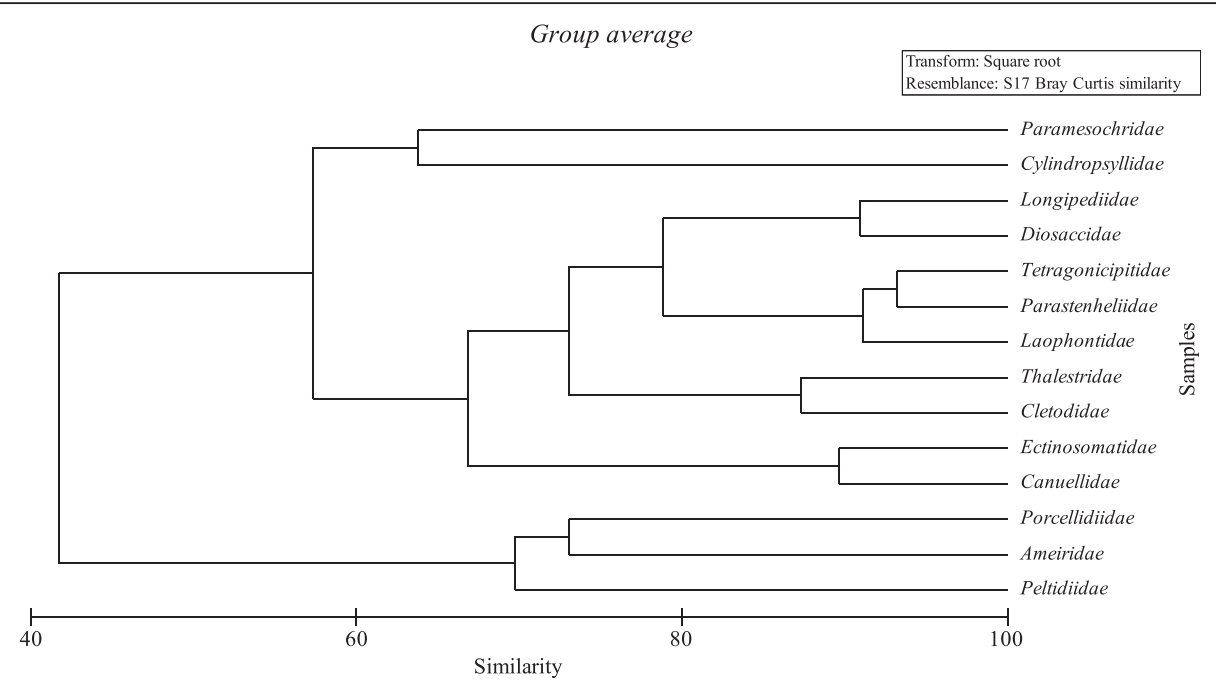

Fig. 3 Classification of families using the Bray-Curtis similarity based on abundance data from the sampled zones 


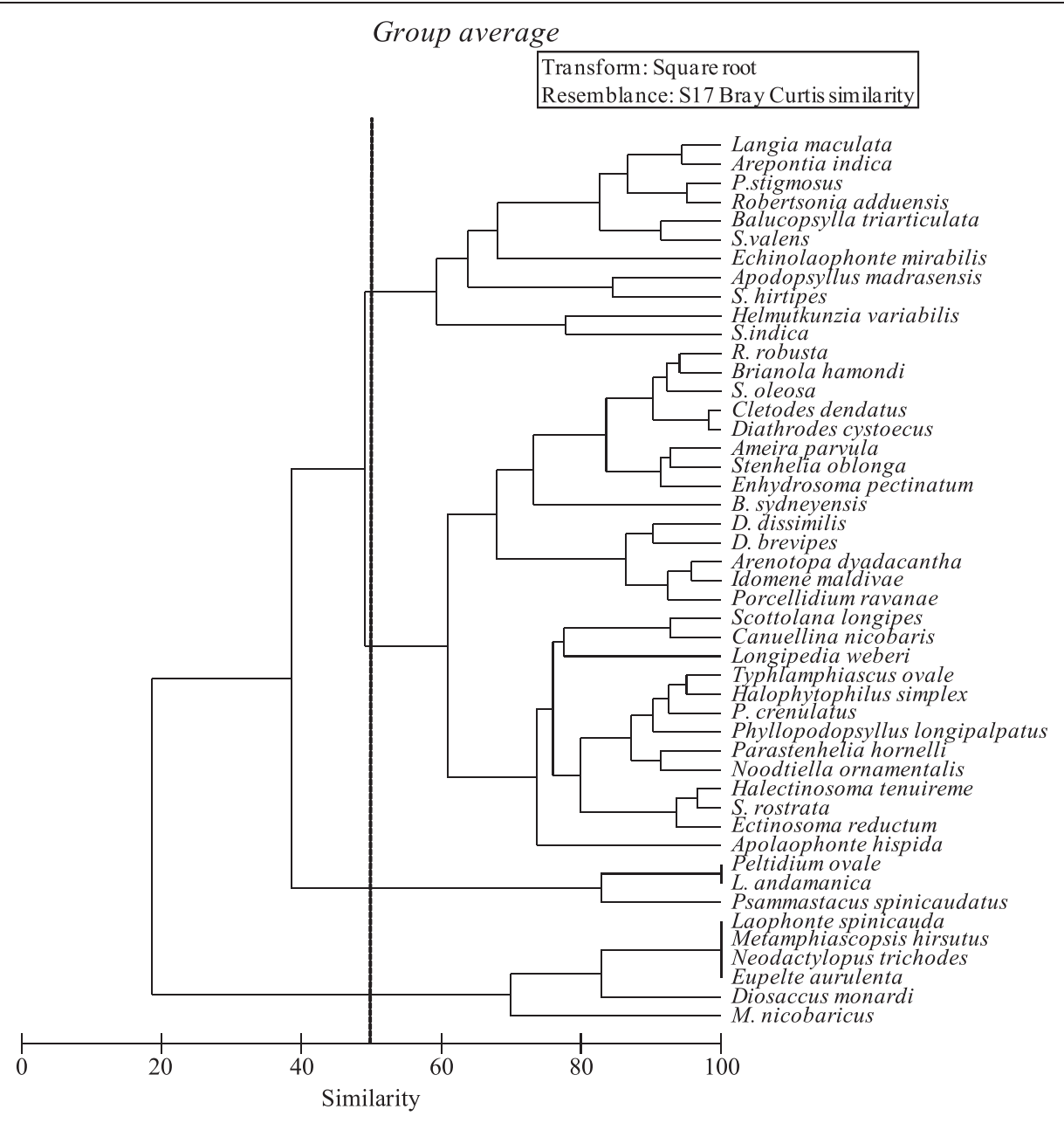

Fig. 4 Dendrogram of cluster analysis. The Bray-Curtis similarity index of the harpacticoid copepods of the studied areas in South Andaman

with the classification of harpacticoids as rare species, migrators, and non-migrators as reported by Walters and Bell (1986) and other investigations of a similar habitat (Mascart et al. 2013, 2015).

A total of 14 families of Harpacticoida were observed, with 8 families (Canuellidae, Ectinosomatidae, Longipediidae, Parastenheliidae, Diosaccidae, Tetragonicipitidae, Cylindropsyllidae, and Laophontidae) found in all zones and 5 families recorded only in the vegetated zone (Porcellidiidae, Peltidiidae, Thalestridae, Ameiridae, and Cletodidae), whereas the family Paramesochridae was confined to the sediments of both zones. True phytaldwelling harpacticoids belong to seven families, namely, Harpacticidae, Tisbidae, Porcellidiidae, Tegastidae, Thalestridae, Diosaccidae, and Peltidiidae (Hicks and Coull 1983); however, in this study, Porcellidiidae and Peltidiidae were least encountered, whereas families such as Harpacticidae, Tisbidae, and Tegastidae were found to be absent. The families Diosaccidae and Canuellidae were rich in species number (37.5\%), contributing 12 and 6 species, respectively, whereas most of the other families contributed 2 to 4 species. Some families like Porcellidiidae, Peltidiidae, Parastenheliidae, Ameiridae, and Paramesochridae contributed only with a single representative throughout the study. The seagrass Thalassia hemprichii preferred for the present study is a subtidal species, and the association of families of Harpacticoida is primarily based on the tidal position (De Troch et al. 2003) and sediment characterization (Gheerardyn et al. 2008; Semprucci et al. 2010). Families like Thalestridae, Laophontidae, Diosaccidae, and Cletodidae were supported by tidal position and showed a strong preference for the subtidal zone (De Troch et al. 2003). The families Porcellidiidae, Peltidiidae, and Thalestridae have been regarded as typical phytal dwellers (Arroyo et al. 2006) and were found only in the vegetated samples. Most species represented in such families typically have flattened bodies and mouth parts adapted to facilitate adhesions to flat leaf or algal surfaces and cope with turbulence and current (Hicks 1985). The family Parastenheliidae was found in all samples of leaf blades, canopy sediment, and unvegetated sediments throughout the period of 

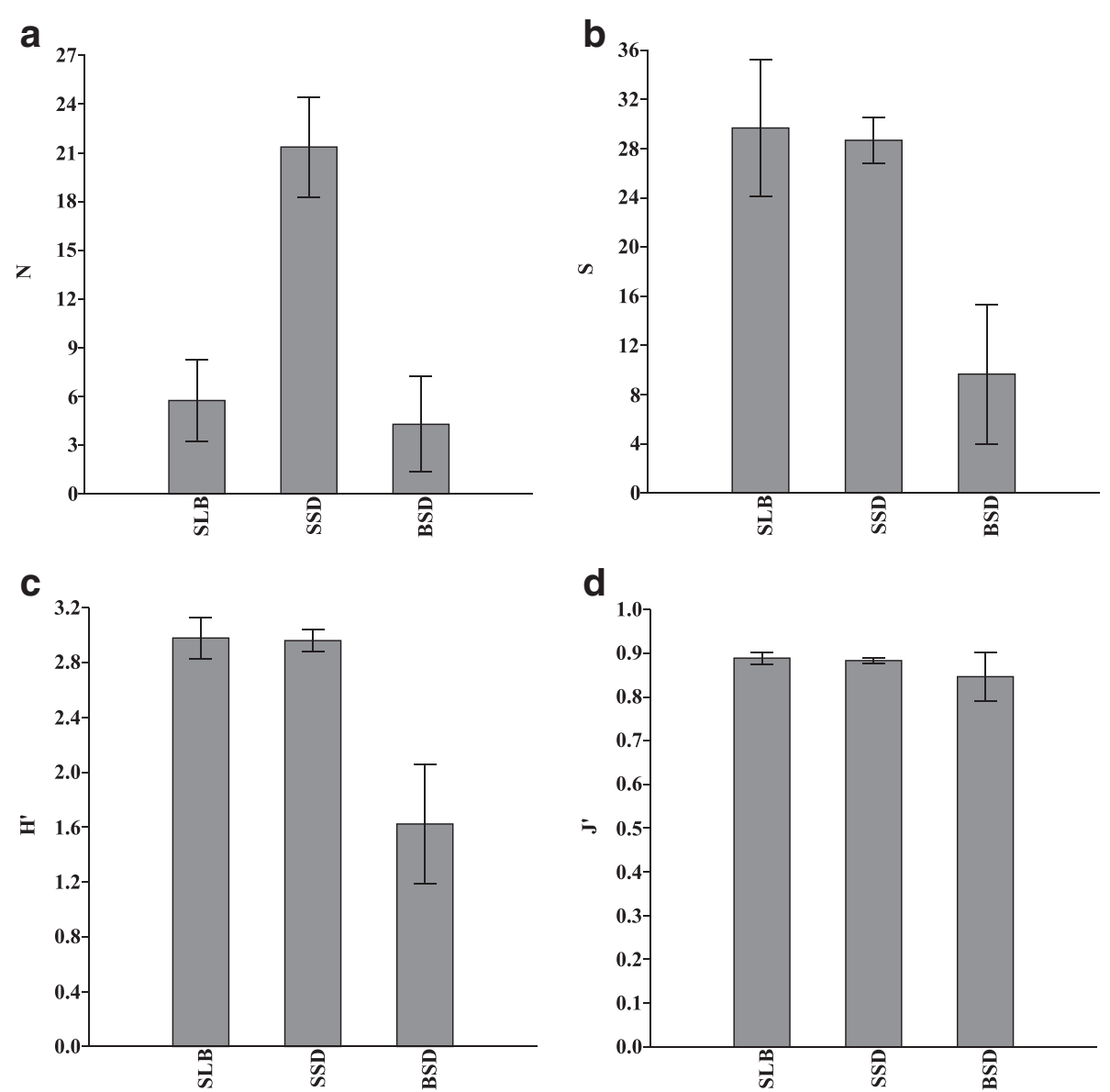

Fig. 5 Diversity indices of harpacticoid copepods. a Abundance $(N)$. b Species richness. c Shannon diversity $\left(H^{\prime}\right)$. d Equitability $\left(J^{\prime}\right)$ in seagrass leaf blade (SLB), seagrass sediment (SSD), and bare sediment (BSD)

sampling. This is explained by the non-specificity of its representatives with respect to substrate.

Most harpacticoid copepods species were found to be common and regular in the vegetated region with higher density in sediments (Fig. 5a). From this, it may be assumed that benthic copepods migrate from sediments to phytal structures. The dendrogram based on the average abundance of species provided five clusters. In the vegetative zone, sediment under seagrass contributed to the species abundance with a total of 13 species with the dominating species Longipedia weberi, Canuellina nicobaris, and Scottolana longipes. Certain species such as Diathrodes cystoecus, Cletodes dentatus, and Scottolana oleosa were found to be abundant and occurred only in the SSD zone congregated as a single cluster (Fig. 4). The local concentrations of harpacticoids could arise in nature from the patchiness in the distribution of microbes (Gray 1968) and dissolved organic carbon from seagrass exudates (Penhale and Smith 1977). Among the benthic harpacticoids inhabiting shallow waters, some species have been recognized as temporary plankton because they migrate from the benthic to the pelagic environment (Walters and Bell 1986; Schimode and Shirayama 2006). Compared to the vegetated environment, organisms of the unvegetated environment are commonly exposed to high levels of environmental stress, gravimetric shifts. Food like organic matter are washed away due to water movement of different kinds. Seagrass environments commonly provide a wider range of niche availability for food, shelter, and refuge from predation. The organisms comprising the seagrass communities are not restricted to seagrass habitats but are simply more abundant than in the surrounding environment (Hogarth 2007).

Abundance of crustaceans in seagrass meadows contribute to reduction in the epiphytic biomass, due to grooming which benefits the seagrass plant (Hemminga and Duarte 2000; Hogarth 2007). Niche diversity, providing shelter from predation and physical stress, and available food resources through sediment trapping (Hicks 1985) create a seagrass ecosystem as a highly complex habitat that has been found to increase faunal abundance and diversity relative to unvegetated habitats 
(Connolly 1994; Jenkins et al. 1997; Semprucci et al. 2010). A decline of seagrasses worldwide might be due to direct anthropogenic activities, such as eutrophication and pollution with hazardous agents, invasive species, climate change, and shoreline development. Another reason might be herbivores associated with seagrasses causing secondary damage by allowing the water or pathogens to enter weakened leaves and increase the chance of leaf loss due to wave action (Gambi et al. 2003). Recent studies on meiobenthic assemblages around the coast of islands and mainland of the Indian Ocean continued to be restricted on the relationships that exist between sediment and meiofauna (Semprucci et al. 2010; Mantha et al. 2012a, b). Despite reports on species lists and the distribution of seagrasses, their importance as productive ecosystems remains inadequately evaluated from Andaman Islands as yet.

\section{Additional file}

Additional file 1: Table S1. List of species recorded from the zones of collection.

\section{Competing interests}

The authors declare that they have no competing interests.

\section{Authors' contributions}

RJ designed the study; carried out the collection, analysis, and identification of the meiofauna and copepod species; and performed data analysis. GP designed and coordinated the study and helped to draft the manuscript. IA participated in sample collection and performed the statistical analysis. All authors read and approved the final manuscript.

\section{Acknowledgements}

We thank the authorities of Pondicherry University for providing necessary facilities. The authors are thankful to the reviewers for their critical comments that improved the quality of this paper.

\section{Received: 9 June 2014 Accepted: 2 July 2015}

Published online: 10 July 2015

\section{References}

Anandavelu I, Jayabarathi R, Padmavati G, Jayaraj KA (2013) Epifaunal assemblage on morphologically distinct intertidal seaweeds of Kodiyaghat (South Andaman). India Proc Int Acad Ecol Environ Sci 3(3):229-237

Ansari ZA, Parulekar AH (1994) Meiobenthos in the sediments of seagrass meadows of Lakshadweep atolls, Arabian Sea. Vie Milieu 44(3/4):185-190

Arroyo NL, Maldonado M, Walters K (2006) Within and between plant distribution of harpacticoid copepods in a North Atlantic bed of Laminaria ochroleuca. J Mar Biol Assoc UK 86:309-316

Arunachalam M, Nair NB (1988) Harpacticoid copepods associated with the seagrass Halophila ovalis in the Ashtamudi Estuary, south-west coast of India. Hydrobiologia 167(168):515-522

Boucher G (1997) Structure and biodiversity of nematode assemblages in the SW lagoon of New Caledonia. Coral Reefs 16:177-186

Callens M, Gheerardyn H, Ndaro SGM, De Troch M, Vanreusel A (2011) Harpacticoid copepod colonization of coral fragments in a tropical reef lagoon (Zanzibar, Tanzania). J Mar Biol Assoc UK 92:1-11

Clarke KR, Gorley RN (2006) PRIMER v6: user manual/tutorial. PRIMER-E, Plymouth, UK

Connolly RM (1994) Removal of seagrass canopy: effects on small fish and their prey. J Exp Mar Biol Ecol 184:99-110

Coull BC (1990) Are members of the meiofauna food for higher trophic levels? T Am Microsc Soc 109:233-246
Coull BC, Zo Z, Tietjen JH, Williams BS (1982) Meiofauna of the southeastern United States continental shelf. Bull Mar Sci 32:233-240

Danovaro R, Scopa M, Gambi C, Franschetti S (2007) Trophic importance of subtidal metazoan meiofauna: evidence from in situ exclusion experiments on soft and rocky substrates. Mar Biol 152:339-350

Das HS (1996) Status of seagrass habitats of Andaman and Nicobar coast. SACON Technical Report No.4, Coimbatore, p 32

De Troch M, Mees J, Wakwabi E (1998) Diets of abundant fishes from beach seine catches in seagrass beds of a tropical bay (Gazi Bay, Kenya). Belg J Zool 128:135-154

De Troch M, Friers F, Vincx M (2001) Alpha and beta diversity of harpacticoid copepods in a tropical seagrass bed: the relation between diversity and species' range size distribution. Mar Ecol Prog Ser 215:225-236

De Troch M, Fiers F, Vincx M (2003) Niche segregation and habitat specialisation of harpacticoid copepods in a tropical seagrass bed. Mar Biol 142:345-355

De Troch M, Raes M, Muthumbi A, Gheerardyn H, Vanreusel A (2008) Spatial diversity of nematode and copepod genera of the coral degradation zone along the Kenyan coast, including a test for the use of higher-taxon surrogacy. Afr J Mar Sci 30(1):25-33

Duarte CM, Chiscano CL (1999) Seagrass biomass and production: a reassessment. Aquat Bot 65:159-174

Findlay SEG (1981) Small scale spatial distribution of meiofauna on a mud and sandflat. Estuar Coast Shelf Sci 12:471-484

Gambi MC, van Tussenbroek BI, Brearley A (2003) Mesofaunal borers in seagrasses: world-wide occurrence and a new record of boring polychaetes in the Mexican Caribbean. Aquat Bot 76:65-77

Gheerardyn H, De Troch M, Ndaro SGM, Raes M, Vincx M, Vanreusel A (2008) Community structure and microhabitat preferences of harpacticoid copepods in a tropical reef lagoon (Zanzibar Island, Tanzania). J Mar Biol Assoc UK 88(4):747-758

Gheerardyn H, De Troch M, Vincx M, Vanreusel A (2009) Harpacticoida (Crustacea: Copepoda) associated with cold-water coral substrates in the Porcupine Seabight (NE Atlantic): species composition, diversity and reflections on the origin of the fauna. Sci Mar 73(4):747-760

Gheerardyn H, De Troch M, Vincx M, Vanreusel A (2010) Diversity and community structure of harpacticoid copepods associated with cold-water coral substrates in the Porcupine Seabight (North-East Atlantic). Helgol Mar Res 64:53-62

Giere O (1993) Meiobenthology. The microscopic fauna in aquatic sediments. Springer, New York

Grainger EH (1991) Exploitation of Arctic sea ice by epibenthic copepods. Mar Ecol Prog Ser 7:119-124

Gray JS (1968) An experimental approach to the ecology of the harpacticoid Leptastacus constrictus Lang. J Exp Mar Biol Ecol 2:278-292

Hemminga MA, Duarte CM (2000) Seagrass ecology. Cambridge University Press, Cambridge

Hicks GRF (1985) Meiofauna associated with rocky shore algae. In: Moore PG, Seed R (eds) The ecology of rocky coasts. Hodder and Stoughton, London, pp 36-56

Hicks GRF, Coull BC (1983) The ecology of marine meiobenthic harpacticoid copepods. Oceanogr Mar Biol Annu Rev 21:67-175

Higgins RP, Thiel H (1988) Introduction to the study of meiofauna. Smithsonian Institution Press, London

Hogarth PJ (2007) The biology of mangroves and seagrasses, 2nd edn. Oxford University Press, New York, p 273

Jagtap TG (1991) Distribution of seagrasses along the Indian coast. Aquat Bot 40(4):379-386

Jagtap TG, Inamdar SN (1991) Mapping of seagrass meadows from the Lakshadweep Islands (India), using aerial photographs. J Indian Soc Remote 19:77-81

Jayabarathi R, Padmavati G, Anandavelu I (2012) Abundance and species composition of harpacticoid copepods from a seagrass patch of South Andaman, India. Curr Res J Biol Sci 4(6):717-724

Jenkins GP, May HMA, Wheatley MJ, Holloway MG (1997) Comparison of fish assemblages associated with seagrass and adjacent unvegetated habitats of Port Phillip Bay and Corner Inlet, Victoria, Australia, with emphasis on commercial species. Estuar Coast Shelf Sci 44:569-588

Lang K (1948) Monographie der Harpacticiden, 2 vols. Hakan Ohlsson, Lund Lang K (1965) Copepoda Harpacticoidea from the Californian Pacific Coast. Almqvist and Wiksell, Stockholm, Sweden

Mantha G, Moorthy MSN, Altaff K, Dahms H, Sivakumar K, Hwang JS (2012a) Seasonal shifts of meiofauna community structures on sandy beaches along the Chennai coast, India. Crustaceana 85(1):27-53 
Mantha G, Moorthy MSN, Altaff K, Dahms H, Sivakumar K, Hwang JS (2012b) Community structure of the Harpacticoida (Crustacea: Copepoda) on the Coast of Chennai, India. Zool Stud 51(4):463-475

Mascart T (2010) The role of meiofauna in the energy transfer in a Mediterranean seagrass bed (Calvi, Corsica), France. Master thesis, Ghent University

Mascart T, Lepoint G, De Troch M (2013) Meiofauna and harpacticoid copepods in different habitats of a Mediterranean seagrass meadow. J Mar Biol Assoc UK 93:1-10

Mascart T, Lepoint G, Deschoemaeker S, Binard M (2015) Seasonal variability of meiofauna, especially harpacticoid copepods, in Posidonia oceanica macrophytodetritus accumulations. J Sea Res 95:149-160

McLachlan A (1978) A quantitative analysis of the meiofauna and the chemistry of the redox potential discontinuity zone in a sheltered sandy beach. Estuar Coast Mar Sci 7:275-290

Nakaoka M (2005) Plant-animal interactions in seagrass beds: ongoing and future challenges for understanding population and community dynamics. Popul Ecol 47:167-177

Ndaro S, Ólafsson E (1999) Soft-bottom fauna with emphasis on nematode assemblage structure in a tropical lagoon in Zanzibar, eastern Africa: I. Spatial variability. Hydrobiologia 405:133-148

Nobi EP, Dilipan E, Sivakumar K, Thangaradjou T (2011) Distribution and biology of seagrass resources of Lakshdweep group of Islands, India. Indian J Mar Sci 40(5):624-634

Ólafsson E (1995) Meiobenthos in mangrove areas in eastern Africa with emphasis on assemblage structure of free-living marine nematodes. Hydrobiologia 312:47-57

Ólafsson E (2003) Do macrofauna structure meiofauna assemblages in marine soft-bottoms? A review of experimental studies. Vie Milieu 53:249-265

Ólafsson E, Moore CG (1992) Effects of macroepifauna on developing nematode and harpacticoid assemblages in a subtidal muddy habitat. Mar Ecol Prog Ser 84:161-171

Padmavati G, Haridas P, Nair KKC, Gopalakrishnan TC, Shiney P, Madhupratap M (1998) Vertical distribution of mesozooplankton in the central and eastern Arabian Sea during the winter monsoon. J Plankton Res 20:343-354

Penhale PA, Smith WO (1977) Excretion of dissolved organic carbon by eelgrass (Zostera marina) and its epiphytes. Limnol Oceanogr 22:400-407

Schimode S, Shirayama Y (2006) Diel vertical migration and life strategies of two phytal-dwelling harpacticoids Ambunguipes rufocincta and Eudactylops spectabilis. Plankton Benthos Res 1(1):42-53

Semprucci F, Colantoni P, Baldelli G, Rocchi M, Balsamo M (2010) The distribution of meiofauna on back-reef sandy platforms in the Maldives (Indian Ocean). Mar Ecol 31:592-607

Stoner AW, Ray M, Waite JM (1995) Effects of a large herbivorous gastropod on macrofauna communities in tropical seagrass meadows. Mar Ecol Prog Ser 121:125-137

Sulochanan B, Kumaraguru AK, Korabu LS (2011) Hydrological conditions in seagrass beds in Plak Bay and Gulf of Mannar, southeast coast of India. J Mar Biol Assoc India 53(1):108-115

Thangaradjou T, Sridhar R, Senthilkumar S, Kannan S (2007) Seagrass resource assessment in the Mandapam coast of the Gulf of Mannar Biosphere Reserve India. Appl Ecol Env Res 6(1):139-146

Thangaradjou T, Nobi EP, Dilipan E, Sivakumar K, Susila S (2010) Heavy metal enrichment in seagrasses of Andaman Islands and its implication to the health of the coastal ecosystem. Indian J Mar Sci 39(1):85-91

Thistle D (1978) Harpacticoid dispersion patterns: implications for deep-sea diversity maintenance. J Mar Res 36:377-397

Turner JT (2004) The importance of small planktonic copepods and their roles in pelagic marine food webs. Zool Stud 43:255-266

Umamaheswari R, Ramachandran S, Nobi EP (2009) Mapping the extend of seagrass meadows of Gulf of Mannar Biosphere Reserve, India using IRS ID satellite imagery. Int J Biodivers Conserv 1(5):187-193

Unsworth RKF, Hinder SL, Bodger OG, Unsworth LCC (2014) Food supply depends on seagrass meadows in the coral triangle. Environ Res Lett 9:1-9

Varkey MJ, Murty VSN, Suryanarayana A (1996) Physical oceanography of the Bay of Bengal and Andaman Sea. In: Ansell AD, Gibson RN, Barnes M (eds) Oceanography and marine biology: an annual review. University college London press, London, pp 1-70
Walters K, Bell SS (1986) Diel patterns of active vertical migration in seagrass meiofauna. Mar Ecol Prog Ser 34:95-103

Watzin MC (1983) The effects of meiofauna on setting macrofauna: meiofauna may structure macrofaunal communities. Oecologia (Berl) 59:163-166

Wells JBJ (1976) Key to aid in the identification of marine harpacticoid copepods. University of Aberdeen, UK, Department of Zoology

Wells JBJ, Rao GC (1987) Littoral Harpacticoida (Crustacea: Copepoda) from Andaman and Nicobar Islands. Memoirs of the Zoological Survey of India $16: 1-385$

\section{Submit your manuscript to a SpringerOpen ${ }^{\odot}$ journal and benefit from:}

- Convenient online submission

Rigorous peer review

- Immediate publication on acceptance

- Open access: articles freely available online

- High visibility within the field

- Retaining the copyright to your article

Submit your next manuscript at $>$ springeropen.com 